\title{
Temporary Immersion Bioreactors: Establishment of Cassava
}

\author{
Diego Pascoal Golle ${ }^{1}$, Jana Koefender ${ }^{1}$, Roberta Cattaneo Horn², Natália Piuco ${ }^{1}$, \\ Cristiane Kaiper ${ }^{1} \&$ Juliane Nicolodi Camera ${ }^{1}$ \\ ${ }^{1}$ Alto Jacui Technological Innovation Center, University of Cruz Alta, Cruz Alta, Brazil \\ ${ }^{2}$ Oxidative Stress Laboratory, University of Cruz Alta, Cruz Alta, Brazil \\ Correspondence: Diego Pascoal Golle, Laboratory of Plant Tissue Culture, Alto Jacuí Technological Innovation \\ Center, University of Cruz Alta, Rodovia Municipal Jacob Della Méa, km 5.6, Parada Benito, 98.020-290. Cruz \\ Alta, RS, Brazil. Tel: 55-553-321-1606. E-mail: dgolle@unicruz.edu.br
}

Received: December 10, 2018

Accepted: January 15, 2019 Online Published: March 15, 2019

doi:10.5539/jas.v11n4p176

URL: https://doi.org/10.5539/jas.v11n4p176

This research is financed by the World Bank and by the Program of Technological Poles of the Secretariat of Economic Development, Science and Technology of Rio Grande do Sul State, Brazil.

\begin{abstract}
Cassava (Manihot esculenta Crantz-Euphorbiaceae) is one of the most important crops for world agriculture. It is the main source of many family's calorie intake and contributes toward food security. Its cultivation is necessitated sterile vegetative propagules with essential physiological and genetic quality, which can be obtained by plant tissue culture techniques. However, the maintenance of in vitro propagation processes requires automation, making large-scale production feasible. This work aimed at developing protocols for the establishment of cassava cultivation in Temporary Immersion Bioreactors (TIBs). Two nutrient media (MS medium reduced to half-strength of the salt concentration and the same formulation plus $4,43 \mu \mathrm{M}$ of 6-Benzylaminopurine [BAP]) and different culture cycles were evaluated in Bioreactors (15 minutes of immersion and 4 hours of stationary phase $[15 \mathrm{M} 4 \mathrm{H}] ; 15$ minutes of immersion and 8 hours of stationary phase $[15 \mathrm{M} 8 \mathrm{H}])$. The establishment of culture in bioreactors was promising. Based on our results, the use of MS medium without growth regulators was more effective for shoot formation; there were differences in the $15 \mathrm{M} 4 \mathrm{H}$ cycle when growth regulators were used. However, the $15 \mathrm{M} 8 \mathrm{H}$ cycle had better performance in both treatments: with or without growth regulators. The use of culture medium without BAP led to better rooting; calli formation increased when BAP was used. The present research investigation indicated the use of MS medium reduced to half- strength the salt concentration without the presence of growth regulator and the use of the culture cycle constituted by 15 minutes immersion and 8-hour intervals in stationary phase was effective for Cassava cultivation in TIBs.
\end{abstract}

Keywords: bioreactors, tissue culture, automation, Manihot esculenta

\section{Introduction}

Cassava (Manihot esculenta Crantz-Euphorbiaceae) is a very important crop in several tropical and subtropical regions of the world, especially in countries of Africa, Latin America and the Caribbean (Zhou et al., 2017). Cassava is considered as the main source of calories for many populations in developing countries. Many factors favor the comprehensive geographic distribution of cassava, with emphasis on its growth ability in low-fertility areas, which indicated the potential of this plant to be grown in regions affected by climate changes. Other benefits of cassava are its use for animal feed, starch production, food processing, paper products, textile and pharmaceutical industry (Chauhan et al., 2015). Mongomake et al. (2015) reported that the high purity and solubility of cassava starch is emphasized when compared to potato and corn starches and is an important characteristic for the production of biofuels (Mongomake et al., 2015).

Brazil is the fourth largest producer of cassava in the world (FAO, 2017) and, in 2018, the average yield of production was 21 million tons (IBGE, 2018). Cassava is propagated vegetatively (Alves, 2006). However, the multiplication by this method is low, which reduces the availability of vegetative materials of high quality and stagnates the production (Santos et al., 2009). Another important aspect is the traditional propagation that can lead to degeneration due to the presence of pathogens; in addition, propagating materials presenting appropriate 
genetic and sanitary conditions are often unavailable. The use of plant tissue culture as a way to increase multiplication is one of the main strategies to obtain propagules with adequate genetic, physiological and sanitary characteristics (Shiji et al., 2014).

The techniques of tissue culture of M. esculenta, and biochemical and physiological aspects were known due to the works of: Fotso et al. (2014), Yandia et al. (2018), Kitimu et al. (2015), Chauhan and Taylor (2018), Kabir et al. (2015), among others. However, in vitro production processes often require a lot of labor and a large need for vials, as well as a semi-solid medium, which increases the cost of production and hampers automation (Pechel et al., 2007). In this sense, an alternative is a production in Bioreactors, which allow the automation of the processes and stand out for creating a microenvironment that best favors the development (Georgiev et al., 2014).

Bioreactors consist of culture flasks in which reactions and/or biological development occurs. The use has been reported for the in vitro production of many species, including: Musa spp. (Roels et al., 2005), Capsicum chinense (Bello-Bello et al., 2017), Gerbera jamesonii (Frómeta et al., 2017), Stevia rebaudiana (Vives et al., 2018), Ananas comosus (Gómez et al., 2018) and Solanum tuberosum (Tapia et al., 2018). The use of Temporary Immersion Bioreactors (TIBs) presents advantages in comparison to the use of other models, mainly because they are more natural environments for culturing, alternating phases of immersion in the liquid medium with periods of contact only with the sterile environment (Georgiev et al., 2014). Liquid culture media favor the contact of the nutrients with the explants, allow the automation and the renewal of the medium without the need to change the jars, reduce labor difficulties, and generate less physiological stress and hyperhydricity (Máximo et al., 2018).

Based on the above aspects, the objective of this work was to develop a protocol for the establishment of M. esculenta cultures in temporary immersion bioreactors.

\section{Method}

The experiments were developed in the Laboratory of Plant Tissue Culture at the University of Cruz Alta. The sources of explants (obtained from a bulk of different genotypes) were nodal segments with, approximately, $1 \mathrm{~cm}$ in length, obtained since explants were cultivated in vitro for one month. Tecnal ${ }^{\circledR}$ Bioreactors (Figure 1 ), with automation control, were used. The bottles of the bioreactors have a capacity for $1 \mathrm{~L}$, for this experiment $200 \mathrm{~mL}$ of liquid medium was used in each flask. The nutrient medium was autoclaved for 20 minutes at $121{ }^{\circ} \mathrm{C}$ and 1.05 Bar of pressure and $\mathrm{pH}$ adjusted to 5.8 .
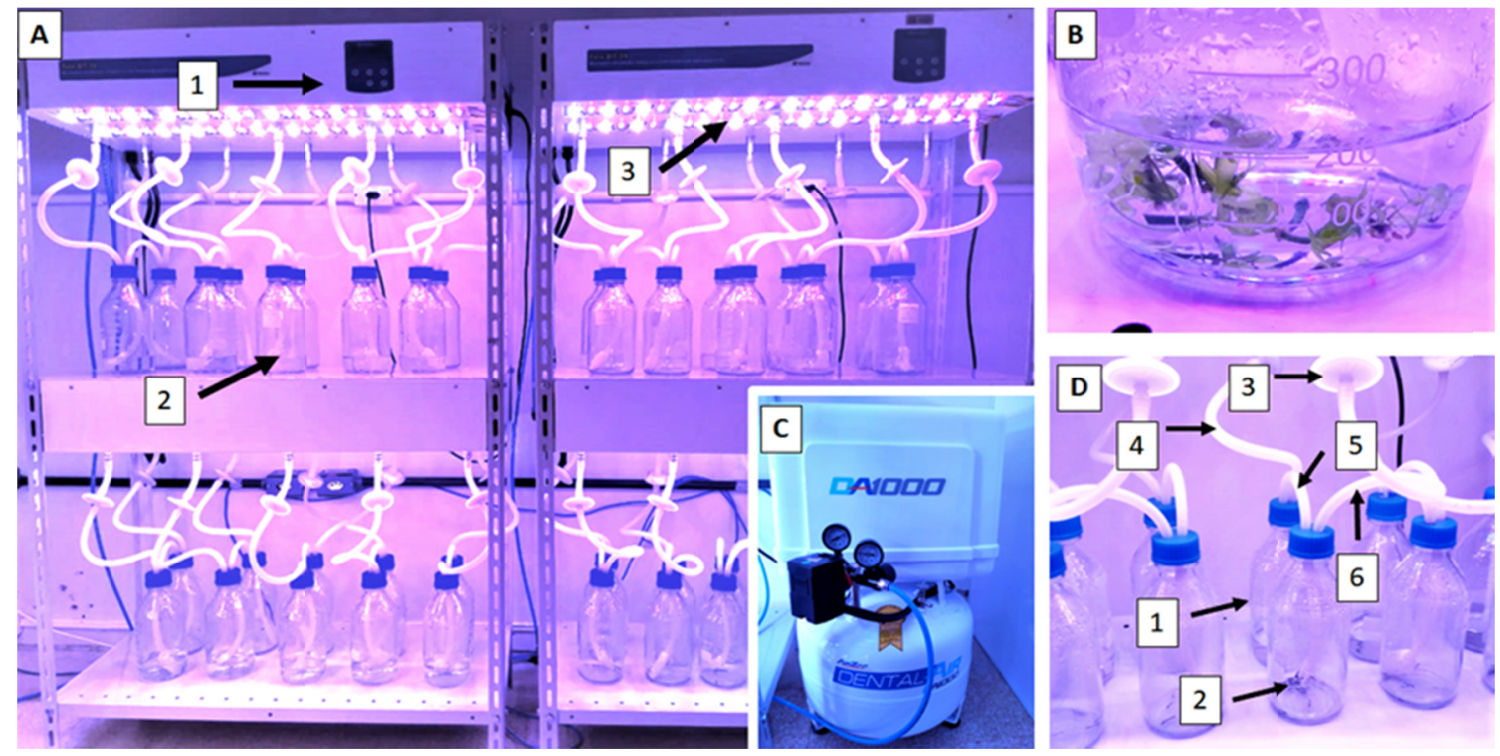

Figure 1. A) Overall aspects of TIBs with arrows in 1-automated control, 2-culture bottles and 3-LED lighting system; B) overall aspect of the cultured explants; C) pressurizer; D) details of the system with 1-storage bottle, 2-culture bottle-when the air was pressurized through the filter (3) in the hose of the storage medium (4), the pressure forced the passage of medium through the connection hose (5) towards the culture bottle and, when the pressure was in the hose connected to the culture bottle (6), the medium returned through the connection hose (5) to the storage bottle 
The experiment was conducted in a completely randomized design, in a $2 \times 2$ factorial scheme. The levels of factor "A" corresponded to the culture media used, being: (1) MS (Murashige \& Skoog, 1962) culture medium reduced to half-strength of salts (1/2MS) and containing $20 \mathrm{~g} \mathrm{~L}^{-1}$ of sucrose, $0.300 \mathrm{mg} \mathrm{L}^{-1}$ of myo-inositol and (2) the same culture media with added with $4,43 \mu \mathrm{M}$ of 6 -Benzulaminopurine (1/2MS + BAP). The levels of factor "B" corresponded to different cycles in the bioreactors: (1) 15 minutes of immersion and 4 hours in stationary phase $(15 \mathrm{M} 4 \mathrm{H})$ and (2) 15 minutes of immersion followed by 8 hours in stationary phase $(15 \mathrm{M} 4 \mathrm{H})$. The stationary phase is the period in which the nutrient medium is in the storage bottles, without contact with the explants. Two levels were used for each factor according to results found by our group. It was not possible increasing the number of levels because the number of bottles in the bioreactor was fixed. Thus, it was necessary reducing the number of treatments to maintain a large number of explants and replicates in the experiment. The pressure used to exchange medium between the culture bottles and the storage bottles was 4 Bars. The conditions of the culture room were $25{ }^{\circ} \mathrm{C}( \pm 3), 16 \mathrm{~h}$ of photoperiod emitted by Light Emitting Diodes (LEDs) with a luminous intensity of $40 \mu \mathrm{mol} \mathrm{m} \mathrm{m}^{-2} \mathrm{~s}^{-1}$.

Different variables including shoot formation (\%), shoot per explant, leaf formation, calli formation (\%) and root formation (\%) were evaluated after 30 days of culturing. Shoot formation was determined based on the emission of new shoots (after establishment in vitro) containing leaves or primordial leaflets. The normality of the data was tested with the use of the Kolmogorov-Smirnov test and the homogeneity of variances by the Bartlett test. The data were then transformed by the $\sqrt{\mathrm{x}+0.5}$ and submitted to Analysis of Variance. The averages were compared using the Tukey's test at 5\% of error probability. Each treatment had 5 replicates, each containing 20 explants, totaling 100 explants per treatment and 400 in total. The experiment was repeated twice and presented very similar data. The herein presented data were selected based on the coefficient of variation in order to assure experimental accuracy (Storck et al., 2006).

\section{Results and Discussion}

The establishment of cassava cultivation in TIBs was promising in all treatments evaluated, and it is possible due to observations made in Figure 2. No significant differences were observed for the factors tested nor interaction regarding the number of shoots per explant $(\mathrm{P}=0.1655$ for factor " $\mathrm{A}$ " levels, $\mathrm{P}=0.5732$ for factor " $\mathrm{B}$ " levels and $\mathrm{P}=0.8090$ for interaction) and number of leaves $(\mathrm{P}=0.1359$ for factor " $\mathrm{A}$ " levels, $\mathrm{P}=0.9855$ for factor " $\mathrm{B}$ " levels and $\mathrm{P}=0.4732$ for interaction). The overall mean number of shoots per explant was 1.68 and the average number of leaves was 1.39 .

Interaction $(\mathrm{P}=0.0407)$ was observed for the percentage of shoot formation (Table 1). The use of the MS medium reduced to half the salt concentration (1/2MS) without the presence of growth regulators was superior in relation to the use of the medium $1 / 2 \mathrm{MS}+\mathrm{BAP}$. When the growth regulator was used, the best shoot formation occurred in the largest interval between the immersion periods was used. However, it should be noted that in both situations the use of the 1/2MS medium was more favorable and also constitutes an alternative better from in the economic point of view, if one takes into consideration the high costs of BAP. 

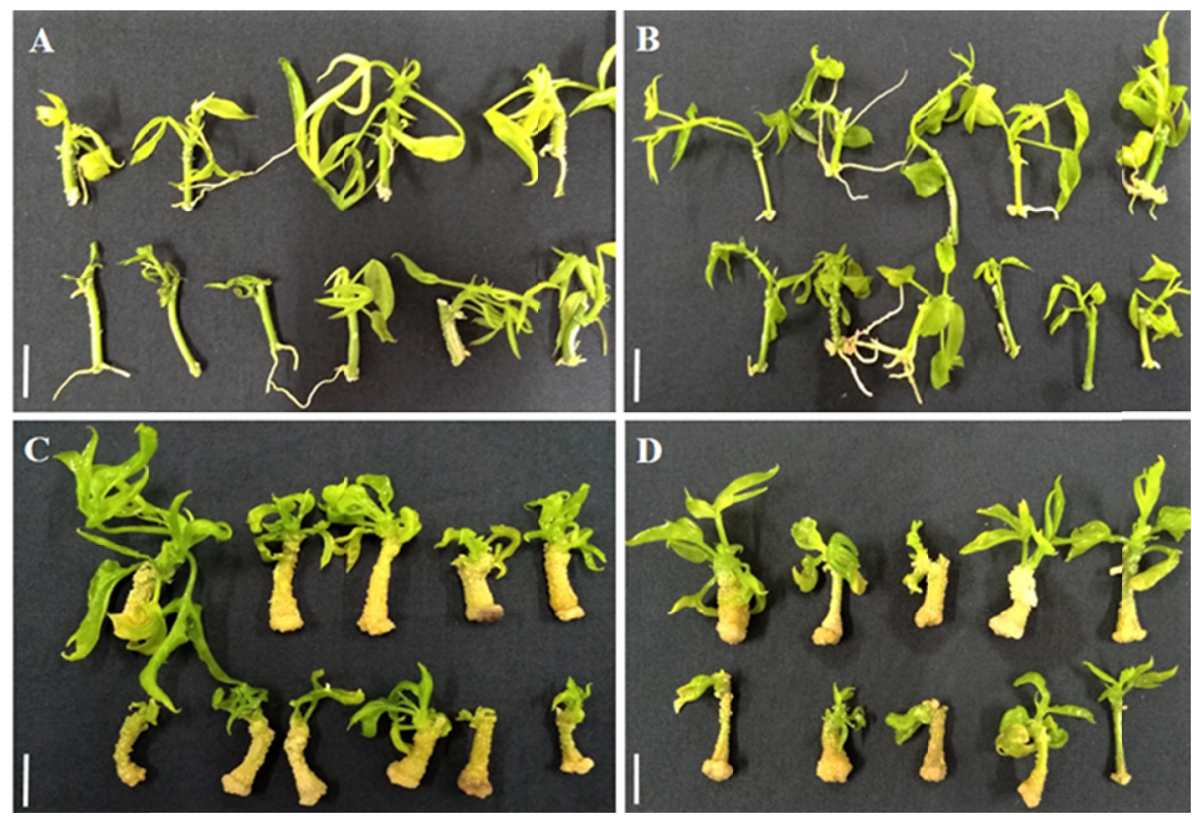

Figure 2. General aspects of the explants according to the different treatments:A) $1 / 2 \mathrm{MS}$ medium and $15 \mathrm{M} 4 \mathrm{H}$ Cycle; B) 1/2MS medium and 15M8H Cycle; C) 1/2MS + BAP medium and 15M4H Cycle; D) 1/2MS + BAP medium and $15 \mathrm{M} 8 \mathrm{H}$ Cycle. Bars $=1 \mathrm{~cm}$

Table 1. Shoot Formation (\%) in cassava explants in TIBs with the use of MS medium half-strength of salts $(1 / 2 \mathrm{MS})$ and MS medium with Growth Regulators (1/2MS + BAP). Cycles of 15 minutes of immersion and 4 hours in stationary phase $(15 \mathrm{M} 4 \mathrm{H})$ and cycles with 15 minutes of immersion and 8 hours of stationary phase $(15 \mathrm{M} 8 \mathrm{H})$

\begin{tabular}{lll}
\hline & $15 \mathrm{M} 4 \mathrm{H}$ & $15 \mathrm{M} 8 \mathrm{H}$ \\
\hline $1 / 2 \mathrm{MS}$ & $100.00 \mathrm{a} \mathrm{A}^{*}$ & $100.00 \mathrm{a} \mathrm{A}$ \\
$1 / 2 \mathrm{MS}+\mathrm{BAP}$ & $87.25 \mathrm{~b} \mathrm{~B}$ & $100.00 \mathrm{a} \mathrm{A}$ \\
\hline $\mathrm{CV}(\%)^{* *}$ & 2.32 & \\
\hline
\end{tabular}

Note. * Averages with different letters (uppercase in the line and lower case in the column) differ from each other by Tukey's test at 5\% error probability. ** Coefficient of Variation measures the experimental accuracy by dividing the square root of the mean square of the experimental error by the overall mean of the experiment.

This result differs from the data found for some species that have been cultivated in bioreactors such as Capsicum chinense, where the best development occurred with the addition of growth regulators to the nutrient medium (Bello-Bello et al., 2010) or in works with Heliconia champneiana (Rodrigues et al., 2006). To use larger stationary phase intervals constitutes an interesting alternative due to the reduction of costs, and the less need to keep the explants in contact with the medium which reduced the possibility of contamination and calli formation.

For rooting and callus formation (Table 2), significant differences were observed only for levels of factor "A", nutrient medium $(\mathrm{P}=0.0011$ and $\mathrm{P}=0.0072$, respectively). The use of the nutrient medium without the presence of growth regulators $(1 / 2 \mathrm{MS})$ favored the formation of roots, which is desirable in the micropropagation process. In contrast, the use of growth regulator reduced rooting and increased calli formation. 
Table 2. Rooting (\%) and Calli Formation (\%) in cassava explants in TIBs with the use of MS medium with half-strength of salts (1/2MS) and MS medium with Growth Regulators (1/2MS + BAP)

\begin{tabular}{lll}
\hline & Rooting $(\%)$ & Calli $(\%)$ \\
\hline $1 / 2 \mathrm{MS}$ & $83.20 \mathrm{a}^{*}$ & $10.00 \mathrm{a}$ \\
$1 / 2 \mathrm{MS}+\mathrm{BAP}$ & $10.00 \mathrm{~b}$ & $80.00 \mathrm{~b}$ \\
\hline $\mathrm{CV}(\%)^{* *}$ & 16.50 & 14.07 \\
\hline
\end{tabular}

Note. * Averages with different letters, in the column, differ from each other by Tukey's test at 5\% error probability. $* *$ Coefficient of Variation measures the experimental accuracy by dividing the square root of the mean square of the experimental error by the overall mean of the experiment.

Grattapaglia and Machado (1998) reported that the use of cytokinin BAP can lead to callogen formation when the availability is balanced with auxins from the culture medium or endogenous to the explants, similar to what was observed in the present study. In addition, when no cytokinin is used, endogenous auxins tend to favor the establishment of morphogenic routes for rooting occurrence. In Bioreactors, cultivation of ginseng, Panax quinquefolius, the use of cytokinins favored the development and multiplication (Uchendu et al., 2011), unlike results recorded for cassava plants in the current study, whose growth regulator did not favor multiplication.

Based on the results of this study, the cultivation of cassava in temporary immersion bioreactors is promising, and for the establishment of the explants. The best result was obtained using $1 / 2 \mathrm{MS}$ culture medium without growth regulators and using the culture cycle of 15 immersion minutes and intervals of 8 hours of stationary phase. This outcome assures a valuable tool for cassava mass multiplication in automated systems. It allows the production of vegetative material with high-quality genetic, physiological and sanitary aspects. It is necessary conducting further studies comprising other variations in growth regulators (which was limited in the current survey due to the size of the bioreactor and its capacity to hold bottles). It is also worth conducting studies with different genotypes and acclimation systems.

\section{References}

Alves, A. A. C. (2006). Fisiologia da mandioca. EMBRAPA Mandioca e Fruticultura Tropical. Aspectos socioeconômicos e agronômicos da mandioca (pp. 138-169). Cruz das Almas, BA: EMBRAPA.

Bello-Bello, J. J., Flick, A. C., Balam-Uc, E., Gómez-Ucand, E., Robert, M. L., Iglesias-Andreu, L. G., \& Buzzy, N. S. (2010). Improvement of in vitro proliferation and elongation of Habanero Pepper shoots (Capsicum chinense Jacq.) by Temporary Immersion. HortScience, 45(7), 1093-1098.

Chauhan, R. D., \& Taylor, N. J. (2018). Meta-topolin stimulates de novo shoot organogenesis and plant regeneration in cassava. Plant Cell, Tissue and Organ Culture, 132(1), 219-224. https://doi.org/10.1007/ s11240-017-1315-3

Chauhan, R. D., Beyene, G., Kalyaeva, M., Fauquet, C. M., \& Taylor, N. (2015). Improvements in Agrobacterium-mediated transformation of cassava (Manihot esculenta Crantz) for large-scale production of transgenic plants. Plant Cell, Tissue and Organ Culture, 121(3), 591-603. https://doi.org/10.1007/ s11240-015-0729-z

FAO (Food and Agriculture Organization of the United Nations). (2017). Food outlook. Biannual report on global food markets.

Fotso, Béni, E. H. D., Ornella, T. A., Carole, D. A., Desire, M. H., \& Denis, O. N. (2014). Effect of exogenous phytohormones and subrose on micropropagation and microtuberisation of Manihot esculenta Crantz. var. TMS 96/0023. African Journal of Biotechnology, 13(39), 3966-3976. https://doi.org/10.5897/AJB2014. 13938

Frómeta, O. M., Escalona, M. M., Silva, J. A. T., Morgado, D. T. P., \& Gradaille, M. A. D. (2017). In vitro propagation of Gerbera jamensonii Bolus ex Hooker f. in temporary immersion bioreactor. Plant Cell, Tissue and Organ Culture, 129(3), 543-551. https://doi.org/10.1007/s11240-017-1186-7

Georgiev, V., Schumann, A., \& Pavlol, A. (2014). Temporary immersion systems in plant biotechnology. Engineering in Lice Sciences, 14(1), 607-627. https://doi.org/10.1002/elsc.201300166

Gómez, D., Hernández, L., Valle, B., Martínez, J., Cid, M., Escalona, M., ... Lorenzo, J. C. (2017). Temporary immersion bioreactors (TIB) provide a versatile cost-effective and reproducible in vitro analysis of the 
response of pineapple shoots to salinity and drought. Acta Physiologiae Plantarum, 39(1), 277-284. https://doi.org/10.1007/s11738-017-2576-5

Grattapaglia, D., \& Machado, M. A. (1998). Micropropagação. In A. C. Torres, L. S. Caldas, \& J. A. Buso (Eds.), Cultura de Tecidos e Transformação Genética de Plantas (pp. 183-260). Brasília: Embrapa Cnph.

Instituto Brasileiro de Geografia e Estatística. (2018). Indicadores IBGE: Estatísticas da Produção Agrícola (p. 80). CEPAGRO: Comissão Especial de Planejamento, Controle e Avaliação das Estatísticas Agropecuárias.

Kabir, M. H., Mamun, A. N. K., Roy, P. K., Islam, M. R., Johan, M. T., \& Talukder, S. U. (2015). In vitro Propagation of Cassava (Manihot esculenta Crantz). Nuclear Science and Applications, 24(1\&2), 23-28.

Kitimu, S. R., Taylor, J., March, T. J., Tairo, F., Wilkinson, M. J., \& López, C. M. R. (2015). Meristem micropropagation of cassava (Manihot esculenta) evokes genome-wide changes in DNA methylation. Frontiers in Plant Science, 6, 1-12. https://doi.org/10.3389/fpls.2015.00590

Máximo, W. P. F., Santos, P. A. A., Marins, G. S., Mendonça, E. G., \& Paiva, L. V. (2018). In vitro multiplication of Eucalyptus hybrid via temporary immersion bioreactor: Culture media and cytokinin effects. Crop Breeding and Applied Biotecnology, 18, 131-138. https://doi.org/10.1590/1984-70332018v18n2a19

Mongomake, K., Doungous, O., Khatabi, B., \& Fondong, V. N. (2015). Somatic embryogenesis and plant regeneration of cassava (Manihot esculenta Crantz) landraces from Cameroon. Springer Plus, 4(477), 1-12. https://doi.org/10.1186/s40064-015-1272-4

Murashige, T., \& Skoog, F. (1962). A revised medium for rapid growth and bio assays with Tobacco Tissue Cultures. Physiologia Plantarum, 15, 473-497. https://doi.org/10.1111/j.1399-3054.1962.tb08052.x

Pechel, R. M., Otoni, W. C., \& Xavier, A. (2007). Tecnologia de biorreatores e propagação fotoautotrófica. In A. Borém (Ed.). Biotecnologia Florestal (pp. 75-92). Viçosa: UFV.

Rodrigues, P. H. V., Teixeira, F. M., Lima, A. M. L. P., \& Ambrosano, G. M. B. (2006). Propagação de mudas de helicônia em biorreator de imersão temporária. Bragantia, 65(1), 29-35. https://doi.org/10.1590/S000687052006000100005

Roels, S., Escalona, M., Cejas, I., Noceda, C., Rodrigues, R., Canal, M. J., ... Debergh, P. (2005). Optimization of plantain (Musa ABB) micropropagation by temporary immersion system. Plant Cell, Tissue and Organ Culture, 82(1), 57-66. https://doi.org/10.1007/s11240-004-6746-y

Shiji, R., George, J., Sunitha, S., Vandhana, A., \& Muthuraj, R. (2014). Effect of NAA and IBA on in vitro regeneration and hardening in cassava (Manihot esculenta Crantz.). Journal of Root Crops, 40(2), 12-20.

Stork, L., Garcia, D. C., Lopes, S. J., \& Estefanel, V. (2006). Experimentação Vegetal (p. 198). Santa Maria: Editora UFSM.

Tapia, M., Arbizu, C., Beraún, F., Lorenzo, J., \& Escalona, M. (2018). Pre-basic seed potato (Solanum tuberosum L.) production using temporary immersion bioreactors. Peruvian Journal of Agronomy, 2, 9-14. https://doi.org/10.21704/pja.v2i1.1127

Uchendu, E. E., Paliyath, G., Brown, D. C. W., \& Saxena, P. K. (2011). In vitro propagation of North American ginseng (Panax quinquefolius L.). Plant Cellular \& Developmental Biology, 47(6), 710-718. https://doi.org/ 10.1007/s11627-011-9379-y

Vives, K., Andújar, I., Lorenzo, J. C., Concepción, O., Hernández, M., \& Esscalona, M. (2017). Comparison of different in vitro micropropagation methods of Stevia rebaudiana B. including temporary immersion bioreactor (BIT®). Plant Cell, Tissue and Organ Culture, 131(1), 195-199. https://doi.org/10.1007/ s11240-017-1258-8

Yandia, S. P., Gandonou, C. B., Silla, S., Zinga, I., \& Toukourou, F. (2018). Response of four cultivars of cassava (Manihot esculenta Crantz.) plantlets free of cassava mosaic vírus to micropropagation in different media. African Journal of Biotechnology, 17(1), 9-16. https://doi.org/10.5897/AJB2016.16235

Zhou, H., Zeng, W., \& Yan, H. (2017). In vitro induction of tetraploids in cassava variety "Xinxuan 048" using colchicine. Plant Cell, Tissue and Organ Culture, 128(3), 723-729. https://doi.org/10.1007/s11240-016$1141-\mathrm{z}$ 


\section{Copyrights}

Copyright for this article is retained by the author(s), with first publication rights granted to the journal.

This is an open-access article distributed under the terms and conditions of the Creative Commons Attribution license (http://creativecommons.org/licenses/by/4.0/). 